\title{
Evaluation of Medicinally Important Constituents of Cotoneaster afghanicus G.Klotz Collected from Baluchistan Region of Pakistan
}

\author{
SHAZIAA. BUKHARI, M. QASIM ${ }^{1}$, M. S. MASOUD¹, MAHMOOD-UR-RAHMAN ${ }^{1}$, H. ANWAR², A. WAQAS AND G. MUSTAFA* \\ Department of Biochemistry, ${ }^{1}$ Department of Bioinformatics and Biotechnology, ${ }^{2}$ Department of Physiology, Government \\ College University, Faisalabad-38060, Pakistan
}

\section{Bukhari et al.: Medicinal importance of Cotoneaster afghanicus}

\begin{abstract}
Cotoneaster afghanicus G.Klotz, indigenous to mountainous parts of China, Afghanistan and Pakistan is also present in Baluchistan region of Pakistan and has medicinally important fixed oils and essential oils. The oils and chemical compounds extracted from Cotoneaster afghanicus were subjected to chemical analyses and evaluation of antioxidant, antibacterial, biofilm inhibiting, thrombolytic and cytotoxic effects. Fixed and essential oils were characterized by gas chromatography-mass spectrometry, which enabled identification of 4 and 14 compounds. Fixed oil showed significant antioxidant (64.67\% scavenging of 2,2-diphenyl-1picrylhydrazyl radical) and antibacterial $(7 \mathrm{~mm}$ zone of inhibition for Gram-positive bacteria) activities. Ethanol extract $(355 \mathrm{mg} / 100 \mathrm{~g}$ of sample) showed highest biofilm inhibitory activity $(54.63 \%)$ among the extracted compounds. Essential oil and ethanol extract also showed notable antioxidant effect with less cytotoxic effect indicating that these are good biologically active agents. The results of this study suggest to further investigate the use of extracted oils and chemical compounds as treatments for local ailments.
\end{abstract}

Key words: Cotoneaster afghanicus, fixed oils, essential oils, ethanol extract, biofilm inhibition, antioxidant, antibacterial

Cotoneaster afghanicus G.Klotz belongs to the Rosaceae family, which represents medium sized plants distributed worldwide, with 95-125 genera and 28253500 species $^{[1]}$. Genus Cotoneaster is commonly found in temperate regions of Asia, Europe and North Africa. It is widely distributed in mountainous parts of China, Afghanistan and Pakistan with about 300 different species. Plants from this genus are woody and vary in size from $0.2 \mathrm{~m}$ shrubs to $20 \mathrm{~m}$ trees ${ }^{[2]}$. This genus attained popularity due to its ornamental plants, which were shown to contain medicinally active compounds. Different plants of this family have been reported to possess antioxidant, antibacterial, antifungal, anticancer, cytotoxic, antihemolytic, hepato-protective and thrombolytic activities ${ }^{[3-6]}$.

C. acuminatus Lind. is a shrub and commonly used as medicinal plant in some areas of Pakistan. The powder of its roots is used to treat hypertension ${ }^{[7]}$. A number of phytochemicals have been identified from genus Cotoneaster. The most common phytochemicals have been flavonoids, isoflavonols, phenols and aromatic esters $^{[8,9]}$. Flavonoids have different activities including

${ }^{*}$ Address for correspondence E-mail: gmustafa_uaf@yahoo.com

March-April 2019 antimicrobial, antiangiogenic, antiinflammatory, antiallergic, hepatoprotective and apoptotic ${ }^{[10]}$. C. racemiflora methanol extract has been reported to possess five compounds, racemiside, scopoletin, 7,8-dimethoxy-6-hydroxycoumarin, 3,3',4'-tri-omethyl ellagic acid and cereotagloperoxide exhibiting antioxidant activities ${ }^{[11]}$. Similarly, the methanol extract of $C$. nummularioides showed strong antibacterial activity against Gram-positive bacteria and the minimum inhibitory concentrations was found to be $3.125 \mathrm{mg} / \mathrm{ml}$ for Bacillus cereus and $6.25 \mathrm{mg} /$ $\mathrm{ml}$ for Staphylococcus aureus ${ }^{[12]}$. In another study, Uysal et al.$^{[13]}$ reported that methanol extract of twigs of $C$. integerrimus exerted strong biological effects and 18 phenolics were identified in the extract. From all the constituents, (-)-epicatechin was found to be the

This is an open access article distributed under the terms of the Creative Commons Attribution-NonCommercial-ShareAlike 3.0 License, which allows others to remix, tweak, and build upon the work non-commercially, as long as the author is credited and the new creations are licensed under the identical terms

Accepted 02 February 2019

Revised 19 August 2018

Received 24 March 2018

Indian J Pharm Sci 2019;81(2):259-265 
major one responsible for observed activities. The polar and apolar fruit extracts of C. pannosus displayed significant radical scavenging activity and inhibitory effects against monoamine oxidase, tyrosinase and $\alpha$-glucosidase that make this plant a potential candidate in functional foods ${ }^{[14]}$. In this context, present research work was carried out to evaluate the medicinal potential of $C$. afghanicus fixed oil (FO), essential oil (EO) and ethanol extract (EE) for various biochemical activities.

\section{MATERIALS AND METHODS}

\section{Collection of plant samples:}

C. afghanicus was collected and taxonomic identification was carried out in the Department of Botany, University of Baluchistan, Quetta, Pakistan. C. afghanicus was taken as a whole (with roots, shoots, leaves and flowers) and stored in the laboratory.

\section{Extraction of FO, EO and EE:}

The whole plant was washed under tap water to remove dust particles and dried in a shade. After drying, the plant material was ground to a powder to extract FOs and EOs ${ }^{[15]}$. Briefly, to extract EOs, finely ground plant material $(100 \mathrm{~g})$ was added to a flask of a hydro-distillation unit with distilled water for $3 \mathrm{~h}$ using Clevenger apparatus ${ }^{[16]}$. EOs obtained after distillation process had some water, which was removed by anhydrous $\mathrm{Na}_{2} \mathrm{SO}_{4}$ and filtered with micro filter (pore size of $0.45 \mu \mathrm{m}$ ) and stored at $-4^{\circ}$ until used.

FOs were extracted using a Soxhlet apparatus following the method described by Dutta et al. ${ }^{[17]}$ with some modifications. Briefly, $20 \mathrm{~g}$ of ground plant material was packed in filter paper thimble stapled and subjected to Soxhlet extraction. $\mathrm{n}$-Hexane $(250 \mathrm{ml})$ was added to a round bottom flask and Soxhlet was adjusted on it with a reflux condenser for $3 \mathrm{~h}$. After that, n-hexane was evaporated under vacuum in a rotary apparatus.

\section{Determination of antioxidant activity:}

Free radical scavenging assay method described by Riaz et al. ${ }^{[18]}$ was used to determine the antioxidant potential of $C$. afghanicus FO, EO and the EE using the 2,2-diphenyl-1-picrylhydrazyl (DPPH) assay. Briefly, the stock solutions of FO, EO and EE were prepared. Ten milligrams of FO, EO and EE were dissolved in $10 \mathrm{ml}$ of methanol. Then $2 \mathrm{ml}$ from each stock solution was taken in a test tube and $2 \mathrm{ml}$ stock solution of DPPH was added and absorbance at $515 \mathrm{~nm}$ was measured. Another test tube was prepared with distilled water instead of stock solution with DPPH solution to serve as a blank. Percent scavenging was calculated using the following Eqn., DPPH scavenging $(\%)=\left(\mathrm{Abs}_{\text {blank }}{ }^{-}\right.$ $\mathrm{Abs}_{\text {sample }} / \mathrm{Abs}_{\text {blank }} \times 100$. The experiment was done in triplicate and the mean was used for further analyses.

\section{Antibacterial activity:}

Antibacterial assay was performed by disc diffusion method $^{[19,20]}$. Briefly, $100 \mu \mathrm{l}$ of bacterial inoculum was gently distributed equally on agar plates. EE was dissolved in $10 \%$ dimethylsulfoxide to a final concentration of $1 \mathrm{mg} / \mathrm{ml}$. Small filter paper discs (9 $\mathrm{mm}$ in size) were laid flat on growth medium containing $100 \mu \mathrm{l}$ of FO, EO and EE of the plant and petri plates were incubated at $37^{\circ}$ for $24 \mathrm{~h}$. Filter paper discs containing extracts with antibacterial activity formed inhibition zones around them, which were measured in $\mathrm{mm}$.

\section{Biofilm inhibition assay:}

A sterile plastic 96-well plate with flat bottom was filled with $100 \mu \mathrm{l}$ of nutrient broth (Oxoid, UK). Then, $100 \mu \mathrm{l}$ of FO, EO and EE was inoculated with bacterial suspension of $20 \mu \mathrm{l}$ into the wells separately. Nutrient broth present in the wells with bacteria acted as control and rifampicin was added to two or three wells acted as standard. Then the 96-well plate was covered and incubated at $34^{\circ}$ for $24 \mathrm{~h}$ in a temperature-controlled incubator in aerobic conditions. After incubation, each well was washed thrice with sterile phosphate buffer ( $220 \mu 1$ to each well). The plate was shaken well to remove non-adherent bacteria from wells. The wells were left to dry after discarding the solvent. To stain each well, $220 \mu 1$ of $5 \%$ crystal violet was added and incubated for $5 \mathrm{~min}$. The plate was air-dried and the dye bound was re-solubilized with $220 \mu 1$ of $33 \%$ (v/v) glacial acetic acid. Optical density was measured for each well at $630 \mathrm{~nm}$ using a microplate reader (BioTek, USA $)^{[21]}$. The bacterial growth inhibition percent (INH \%) was calculated using the following Eqn., INH $(\%)=1-\mathrm{OD}_{630 \text { (sample) }} / \mathrm{OD}_{630 \text { (control) }} \times 100$.

\section{Thrombolytic activity:}

Clot lysing activity was assessed using the method described by Prasad et al. ${ }^{[22]}$. Five millilitres of venous blood was drawn from healthy volunteers. Blood was distributed equally into five separate pre-weighed microfuge tubes $\left(\mathrm{W}_{1}\right)$ centrifuged at $2500 \mathrm{rpm}$ for $5 \mathrm{~min}$ and incubated at $37^{\circ}$ for $45 \mathrm{~min}$ to clot the blood. After blood clotting, serum was carefully decanted and the tubes containing clot were weighed again $\left(\mathrm{W}_{2}\right) . \mathrm{W}_{1}$ 
was subtracted from $\mathrm{W}_{2}$ to gain the clot weight $\left(\mathrm{W}_{\mathrm{C}}\right)$. Then $100 \mu \mathrm{l}$ of FO, EO and EE were added to the clot containing microfuge tubes. As a standard, $100 \mu \mathrm{l}$ of streptokinase was added to a clot containing tube and labelled as standard. In the same way, to make a blank, $100 \mu \mathrm{l}$ of distilled water was added to a clot containing microfuge tube and labelled. All the microfuge tubes were incubated at $37^{\circ}$ for $90 \mathrm{~min}$. They were removed and weighed again $\left(\mathrm{W}_{\mathrm{L}}\right)$. To obtain the weight loss due to lysis, $\mathrm{W}_{\mathrm{L}}$ was subtracted from $\mathrm{W}_{\mathrm{C}}$. The following formulae were used to calculate percent weight loss due to clot lysis for each microfuge tube: clot weight $\left(\mathrm{W}_{\mathrm{c}}\right)=\mathrm{W}_{2}-\mathrm{W}_{1}$; percent clot lysis $=($ weight of released clot $) /($ clot weight $) \times 100$.

\section{Haemolytic activity:}

Haemolytic activity was determined according to the method of Kalpana et al. ${ }^{[23]}$. Briefly, calf thymus DNA (CT-DNA) was taken $(0.5 \mu \mathrm{g} / \mu \mathrm{l})$ and diluted three folds $(0.5 \mu \mathrm{g} / 3 \mu \mathrm{l})$ using $50 \mathrm{mM}$ sodium phosphate buffer ( $\mathrm{pH}$ 7.4). Then $3 \mu \mathrm{l}$ of the diluted CT-DNA was treated with $5 \mu \mathrm{l}$ of test sample. After this, $4 \mu \mathrm{l}$ of the $30 \% \mathrm{H}_{2} \mathrm{O}_{2}$ was added in the presence of FO, EO and $\mathrm{EE}$ of the plant. The final volume $(15 \mu \mathrm{l})$ was made with same buffer. A solution of $3 \mu \mathrm{l}$ of CT-DNA with $11 \mu \mathrm{l}$ of sodium phosphate was used as a negative control. The $3 \mu \mathrm{l}$ of CT-DNA treated with $4 \mu \mathrm{l}$ of the $30 \% \mathrm{H}_{2} \mathrm{O}_{2}$ (final volume of $15 \mu \mathrm{l}$ was made with sodium phosphate buffer) was used as a positive control. DNA was run on $1 \%$ horizontal agarose gel.

\section{Gas chromatography-mass spectrometry (GC-MS) analysis:}

The samples were analysed using a GC 6850 network GC system equipped with a 7683B series auto injector and 5973 inert mass selective detector (Agilent Technologies, Willmington, DE, USA). Compounds were separated on an HP-5 MS capillary column with a $5 \%$ phenyl polysiloxane stationary phase $(30.0 \mathrm{~m} \times$ $0.25 \mathrm{~mm}$, film thickness $0.25 \mu \mathrm{m}$ ). Oven temperature was programmed in a three step gradient: initial temperature set at $45^{\circ}$ (held for $5 \mathrm{~min}$ ), ramped till $150^{\circ}$ at $10^{\circ} / \mathrm{min}$, followed by a $5^{\circ} / \mathrm{min}$ rise till $280^{\circ}$ and finally at $15^{\circ} / \mathrm{min}$ to $325^{\circ}$ where it was held for $5 \mathrm{~min}$. Helium gas flow rate was $1.1 \mathrm{ml} / \mathrm{min}$ (pressure $60 \mathrm{kPa}$ and linear velocity $38.2 \mathrm{~cm} / \mathrm{s}$ ). Ions/fragments were monitored in scanning mode through $40-550 \mathrm{~m} / \mathrm{z}^{[15,19]}$.

\section{Statistical analysis:}

The results obtained were presented by means \pm standard deviation.

\section{RESULTS AND DISCUSSION}

FO, EO and EE of C. afghanicus were prepared and analysed to find out if these possessed biological activity. This is the first report of exploring pharmacologic potential of $C$. afghanicus. The yields of FO, EO and EE per $100 \mathrm{~g}$ of C. afghanicus plant material were $855 \pm 4.358,31 \pm 2.0$ and $355 \pm 4.44 \mathrm{mg}$, respectively.

From C. afghanicus FO, 4 components (fig. 1A) and from the EO, 14 components (fig. 1B) were identified with the help of GC/MS. The name of these compounds, molecular weight, retention time, percent area and percent quality have been shown in Table 1 . These results indicated that monoterpene hydrocarbons were $24.76 \%$, oxygenated monoterpenes were $53.8 \%$, sesquiterpenes were 3.48 and $0.21 \%$ were oxygenated sesquiterpenes in the $\mathrm{EO}$ of $C$. afghanicus. The extracts

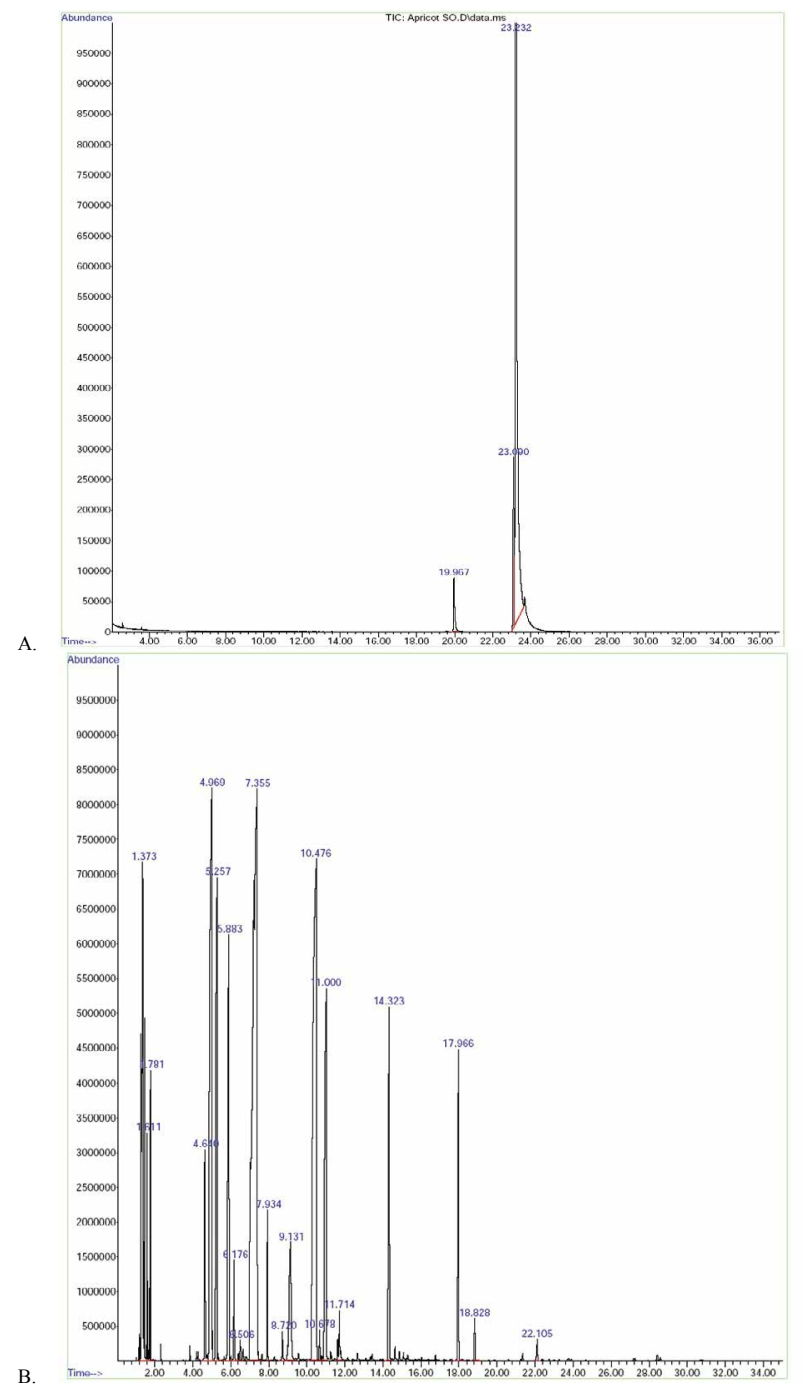

Fig. 1: GC-MS analysis of Cotoneaster afghanicus GC-MS analysis of Cotoneaster afghanicus showing (A) fixed oils and (B) essential oils 
of $C$. afghanicus have shown different degrees of activities in various assays ${ }^{[15,19,22]}$. It has been reported that monoterpenes and sesquiterpeneshaveantibacterial, antioxidant, thrombolytic and DNA damage protecting abilities $^{[24,25]}$. Monoterpene hydrocarbons could also be used as natural flavouring and preservative agents in foods. Oxygenated monoterpenes and sesquiterpenes have greater antioxidant activities ${ }^{[26]}$.

DPPH assay was performed to evaluate the antioxidant potential of FO, EO and EE $(10 \mathrm{mg} / 10 \mathrm{ml}$ of methanol) of $C$. afghanicus. DPPH on dissolving in water gave a deep violet colour, which became yellow on receiving protons from proton donating species. Greater the loss of colour, greater number of DPPH radicals removed. DPPH radicals scavenged by FO, EO and EE expressed as $\mathrm{EC}_{50}$ values were $57.35 \pm 0.26,43.29 \pm 0.23$ and $64.67 \pm 0.245 \%$, respectively (fig. 2). EE removed the highest $\%$ of DPPH free radicals. FO and EO have also shown notable antioxidant ability. This was due to the presence of palmitic acid, oleic acid and octadecanoic acid in FO and antioxidant activity of EO was due to the presence of oxygenated monoterpenes and sesquiterpenes ${ }^{[27-29]}$.

Antibacterial activity screening results of $C$. afghanicus FO, EO and EE $(1 \mathrm{mg} / \mathrm{ml})$ are given in Table 2. All tested samples showed antibacterial activity against

TABLE 1: COMPOUNDS IDENTIFIED IN FIXED AND ESSENTIAL OILS OF COTONEASTER AFGHANICUS

\begin{tabular}{lccc}
\hline $\begin{array}{l}\text { Retention } \\
\text { time }\end{array}$ & Compound name & Area (\%) & $\begin{array}{c}\text { Quality } \\
\text { (\%) }\end{array}$ \\
\hline \multicolumn{4}{c}{ Compounds identified in fixed oils } \\
\hline 19.95 & Palmitic acid & 4.21 & 98 \\
23.09 & Linolelaidic acid & 13.03 & 99 \\
23.24 & Iso-oleic acid & 80.08 & 99 \\
23.67 & Iso-octadecanoic acid & 2.68 & 94 \\
& Compounds identified in essential oils \\
\hline 4.967 & D-a-Pinene & 11.45 & 96 \\
5.257 & Camphene & 5.99 & 96 \\
5.881 & B-Pinene & 5.47 & 95 \\
6.177 & B-Myrcene & 0.73 & 91 \\
6.504 & a-Phellandrene & 0.22 & 91 \\
7.931 & Y-Terpinene & 0.90 & 95 \\
7.353 & Eucalyptol & 26.20 & 98 \\
10.475 & Camphore & 17.20 & 97 \\
10.676 & Isoborneol & 0.25 & 94 \\
11.003 & Levo-borneol & 6.33 & 94 \\
14.321 & D,L-isobornyl acetate & 3.82 & 98 \\
17.965 & B-Caryophyllene & 3.15 & 99 \\
18.825 & a-Caryophyllene & 0.33 & 98 \\
22.108 & Caryophyllene oxide & 0.21 & 94 \\
\hline
\end{tabular}

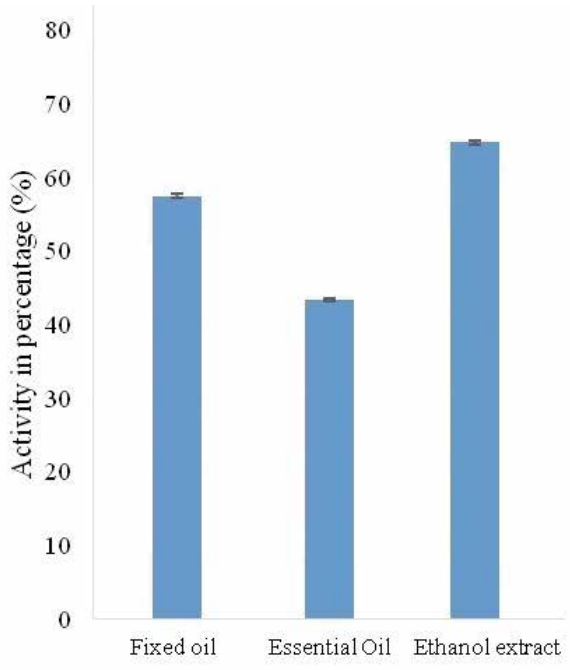

Fig. 2: DPPH radical scavenging by FO, EO and EE

Fixed oil (FO), essential oil (EO) and ethanol extract (EE) of Cotoneaster afghanicus

TABLE 2: ANTIBACTERIAL ACTIVITIES OF COTONEASTER AFGHANICUS

\begin{tabular}{lcc}
\hline $\begin{array}{l}\text { Plant component } \\
(1 \mathrm{mg} / \mathrm{ml})\end{array}$ & $\begin{array}{c}\text { Bacillus subtilis } \\
\text { zone of inhibition } \\
(\mathbf{m m})\end{array}$ & $\begin{array}{c}\text { Escherichia coli } \\
\text { zone of inhibition } \\
(\mathbf{m m})\end{array}$ \\
\hline Fixed oil & $7 \pm 0.08$ & $\mathrm{ND}$ \\
Essential oil & $5 \pm 0.07$ & $\mathrm{ND}$ \\
Ethanol extract & $6 \pm 0.09$ & $3 \pm 0.04$ \\
$\begin{array}{l}\text { Rifampicin } \\
\text { (positive control) }\end{array}$ & $25 \pm 0.25$ & $21 \pm 0.23$ \\
\hline
\end{tabular}

Data presented as mean $\pm S D$ of three independent replicates. ND $=$ not detected

Gram-positive bacterial while FO and EO failed to exert any activity on Gram-negative bacteria tested. The standard rifampicin showed an inhibition zone of $21 \pm 0.23 \mathrm{~mm}$ for Escherichia coli and $25 \pm$ $0.25 \mathrm{~mm}$ for Bacillus subtilis. Results demonstrated that C. afghanicus extracts did not possess any antibacterial activity against Gram-negative bacteria, while moderately active against Gram-positive bacteria. The extracts of $C$. nummularia were reported to exhibit antibacterial properties against human pathogenic strains $^{[30]}$.

Biofilms are attached to microbial cell communities protected by slimy layer. These differ from planktonic cells and show resistance to antibacterial agents. Hence it is essential to identify and develop new naturebased antibacterial agents against these bacteria. C. afghanicus extracts $(100 \quad \mu \mathrm{l} / 20 \quad \mu \mathrm{l}$ bacterial suspension) were also tested against biofilm forming bacteria (B. subtilis). The results showed that EE exhibited $54.63 \pm 0.26 \%$ biofilm inhibiting activity, which was as good as the standard. FO and EO gave $\mathrm{IC}_{50}$ values of $31.61 \pm 0.42$ and $13.96 \pm 0.21 \%$, 


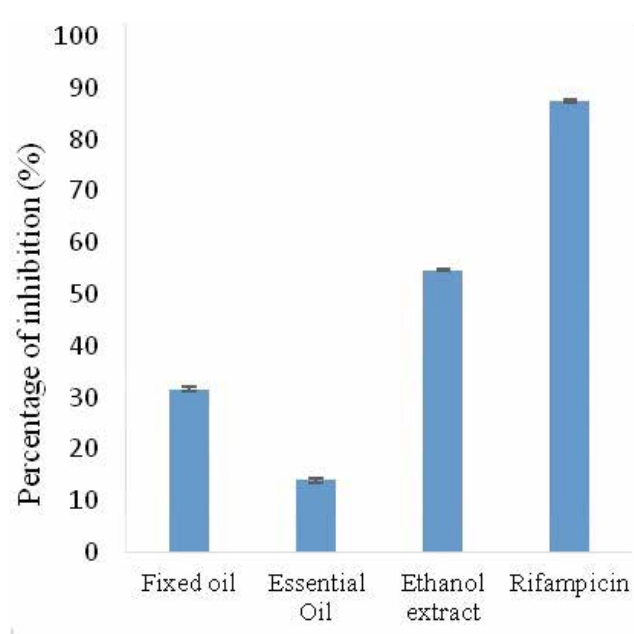

Fig. 3: Cotoneaster afghanicus against biofilm formation Cotoneaster afghanicus extracts tested at $100 \mu \mathrm{l} / 20 \mu \mathrm{l}$ against biofilm forming bacteria

\begin{tabular}{lc}
$\begin{array}{l}\text { TABLE 3: } \\
\text { COTONEASTER AFGHANICUS }\end{array}$ & ACTIVITY OF \\
\begin{tabular}{lc}
\hline \multicolumn{2}{l}{ Plant component (100 } \\
$\mu \mathrm{l} / 833 \mu \mathrm{l}$ blood)
\end{tabular} & Thrombolytic activity $(\%)$ \\
\hline Fixed oil & $13.91 \pm 0.28$ \\
Essential oil & $23.54 \pm 0.46$ \\
Ethanol extract & $14.65 \pm 0.24$ \\
Streptokinase* $^{*}$ & $78.65 \pm 0.75$ \\
Distilled water* & $1.93 \pm 0.19$ \\
\hline
\end{tabular}

*Standard, **negative control

respectively (fig. 3). The antibacterial and biofilm inhibiting activities of these samples tested were due to the presence of flavonoids and terpenoids ${ }^{[31]}$.

To test thrombolytic ability of $C$. afghanicus an in vitro experimental method was designed. C. afghanicus FO, EO and EE $(100 \mu \mathrm{l} / 833 \mu \mathrm{l}$ blood $)$ showed mild thrombolytic activity and results are given in Table 3. According to these results, EO and EE showed more clot lysis than FO. The clot lysis shown by $C$. afghanicus FO, EO and EE were $13.91 \pm 0.28,23.54 \pm 0.46$ and $14.65 \pm 0.24 \%$, respectively. Streptokinase was used as a standard to compare the \% lysis caused by C. afghanicus. Blood clotting leads to different coronary problems ${ }^{[22]}$.

To observe the cytotoxic effect of $C$. afghanicus on RBC, haemolytic assay was performed. Results were expressed as \% lysis calculated by comparing absorbance of plant sample with absorbance of Triton $\mathrm{X}-100$. Triton $\mathrm{X}-100$ was used as a positive control, which showed $100 \%$ lysis and phosphate buffered saline was used as a negative control. Percent lysis caused by FO, EO and EE of C. afghanicus $(20 \mu \mathrm{l} /$ $180 \mu \mathrm{l})$ was $43.36 \pm 1.13,3.94 \pm 0.78$ and $4.69 \pm 0.59 \%$, respectively (fig. 4).
$\mathrm{H}_{2} \mathrm{O}_{2}$-induced CT-DNA damage protection caused by FO, EO and EE of C. afghanicus ( $3 \mu$ CT-DNA/ $5 \mu$ test sample) has been shown in fig. 5. Results indicated that untreated CT-DNA in the first lane was not damaged, but the CT-DNA in lane 2 was highly damaged due to exposure to $\mathrm{H}_{2} \mathrm{O}_{2}$. CT-DNA from lanes 3, 4 and 5 was exposed to $\mathrm{H}_{2} \mathrm{O}_{2}$ in the presence of C. afghanicus FO, EO EE, respectively. CT-DNA in lane 4 was completely protected by EO from $\mathrm{H}_{2} \mathrm{O}_{2}-$ induced damage. CT-DNA was protected to some extent in the presence of FO (lane 3) and EE (lane 5) from $\mathrm{H}_{2} \mathrm{O}_{2}$-induced damage. $\mathrm{EO}$ could protect CT-DNA from $\mathrm{H}_{2} \mathrm{O}_{2}$-induced damage with no toxic effect. In human and other animals RBCs play important role to sustain

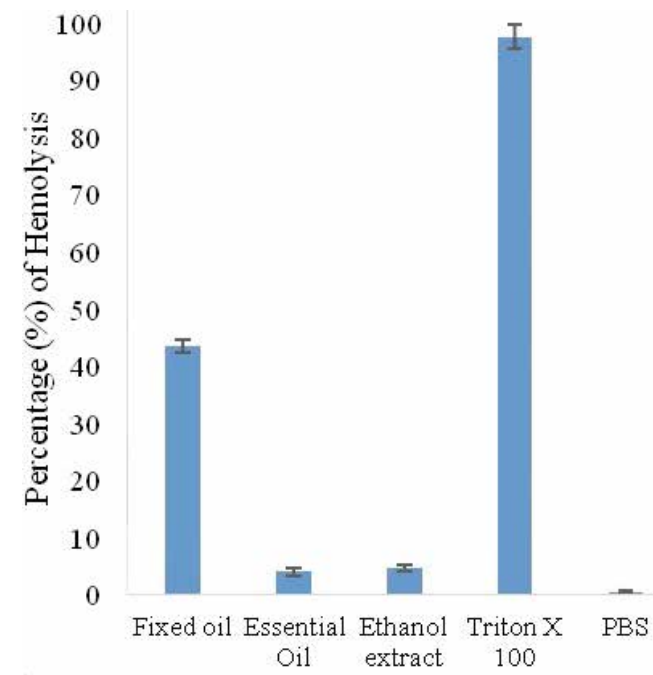

Fig. 4: Percent lysis caused by FO, EO and EE of Cotoneaster afghanicus

Fixed oil (FO), essential oil (EO) and ethanol extract (EE) of Cotoneaster afghanicus

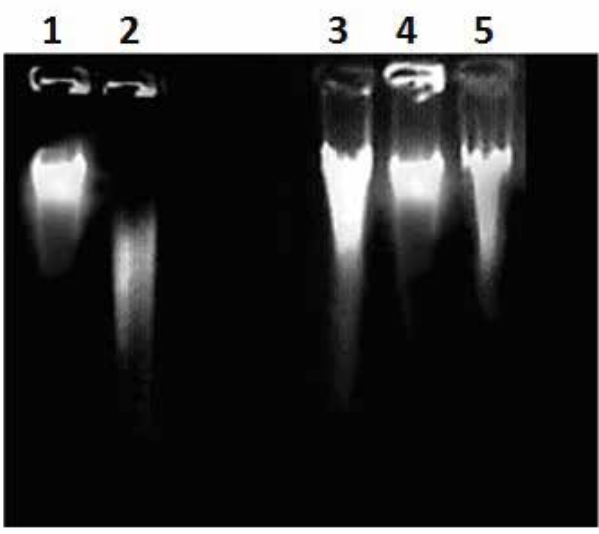

Fig. 5: Protection of $\mathrm{H}_{2} \mathrm{O}_{2}$-induced calf-thymus DNA damage by FO, EO and EE of Cotoneaster afghanicus

Three microlitres of diluted CT-DNA/5 $\mu$ l tested sample. Lane 1- CT-DNA without $\mathrm{H}_{2} \mathrm{O}_{2}$ treatment. Lane 2- CT-DNA treated with $\mathrm{H}_{2} \mathrm{O}_{2}$. Lane 3-CT-DNA treated with $\mathrm{H}_{2} \mathrm{O}_{2}$ in the presence of fixed oil (FO) of $C$. afghanicus. Lane 4- CT-DNA treated with $\mathrm{H}_{2} \mathrm{O}_{2}$ in the presence of essential oil (EO) of Cotoneaster afghanicus. Lane 5- CT-DNA treated with $\mathrm{H}_{2} \mathrm{O}_{2}$ in the presence of ethanol extract (EE) of Cotoneaster afghanicus 
life. If RBCs encounter a cytotoxic compound, cell integrity is lost and lysis occurs. Haemolytic assay was performed to evaluate if the extracts of $C$. afghanicus possessed any cytoprotective activity. Compounds with percent haemolysis lower than 6 are safe for human use. Results showed that cytotoxic effect of EO and EE were less than 5 and hence could be used as a medicine or as a food preservative or flavouring agents ${ }^{[12,19]}$. EO protected DNA from $\mathrm{H}_{2} \mathrm{O}_{2}$-induced damage, probably owing to the presence of different terpenoids reported to be good antioxidants ${ }^{[32]}$. C. afghanicus FO has 4 compounds and EO has 14 compounds in abundance as characterized by GC/MS. All plant extract samples showed good antioxidant activity and EO and EE possessed better potential due to lower cytotoxic effects.

The identification and characterization of fixed and EOs were accomplished using GC/MS profiling. FO was found to exhibited significant antioxidant and antibacterial activities whereas EE was found to have the highest biofilm inhibitory activity among all extracts tested. Antioxidant effect with low cytotoxicity was observed in EO and EE, which appear to have the potential for further development as therapeutic agents.

\section{Acknowledgement:}

The authors gratefully acknowledge the financial support from Higher Education Commission, Islamabad, Government of Pakistan.

\section{Conflict of interest:}

The authors declare no conflict of interest.

\section{REFERENCES}

1. Lingdi L, Alexander C. Spiraea. Flora of China. Vol 9. Beijing, China: Science Press; 2003. p. 47-73.

2. Bartish IV, Hylmö B, Nybom H. RAPD Analysis of interspecific relationships in presumably apomictic Cotoneaster species. Euphytica 2001;120(2):273-80.

3. Mavi A, Terzi Z, Özgen U, Yildirim A, Coşkun M. Antioxidant properties of some medicinal plants: Prangos ferulacea (Apiaceae), Sedum sempervivoides (Crassulaceae), Malva neglecta (Malvaceae), Cruciata taurica (Rubiaceae), Rosa pimpinellifolia (Rosaceae), Galium verum Subsp. verum (Rubiaceae), Urtica dioica (Urticaceae). Biol Pharm Bull 2004;27(5):702-05.

4. Oszmianski J, Wojdylo A, Lamer-Zarawska E, Swiader K. Antioxidant tannins from Rosaceae plant roots. Food Chem 2007;100:579-83.

5. Kostić DA, Velicković JM, Mitić SS, Mitić MN, Randelović SS. Phenolic content, and antioxidant and antimicrobial activities of Crataegus oxyacantha L (Rosaceae) fruit extract from Southeast Serbia. Trop J Pharm Res 2012;11:117-24.
6. Tolentino F, Araújo PA, Marques Ede S, Petreanu M, Andrade $\mathrm{SF}$, Niero R, et al. In vivo evaluation of the genetic toxicity of Rubus niveus Thunb. (Rosaceae) extract and initial screening of its potential chemoprevention against doxorubicin-induced DNA damage. J Ethnopharmacol 2015;164:89-95.

7. Ahmad L, Semotiuk A, Zafar M, Ahmad M, Sultana S, Liu $\mathrm{QR}$, et al. Ethnopharmacological documentation of medicinal plants used for hypertension among the local communities of Dir Lower, Pakistan. J Ethnopharmacol 2015;175:138-46.

8. Chang CS, Jeon JI. Leaf flavonoids in Cotoneaster wilsonii (Rosaceae) from the Island Ulleung-Do, Korea. Biochem Syst Ecol 2003;31:171-9.

9. Khan S, Yasmeen S, Afza N, Malik A, Iqbal L, Lateef M. Cotonoates A and B, new aromatic esters from Cotoneaster racemiflora. Z Naturforsch B 2008;63:1219-22.

10. Hodek P, Trefil P, Stiborová M. Flavonoids-potent and versatile biologically active compounds interacting with cytochromes P450. Chem Biol Interact 2002;139:1-21.

11. Khan S, Riaz N, Afza N, Malik A, Aziz-ur-Rehman, Iqbal L, et al. Antioxidant constituents from Cotoneaster racemiflora. J Asian Nat Prod Res 2009;11:44-48.

12. Sani MA, Yaghooti F. Antibacterial effects and chemical composition of essential oil from Cotoneaster nummularioides leaves extract on typical food-borne pathogens. J Essent Oil Bear P1 2016;19:290-6.

13. Uysal A, Zengin G, Mollica A, Gunes E, Locatelli M, Yilmaz $\mathrm{T}$, et al. Chemical and biological insights on Cotoneaster integerrimus: a new (-)-epicatechin source for food and medicinal applications. Phytomedicine 2016;23:979-88.

14. Les F, López V, Caprioli G, Iannarelli R, Fiorini D, Innocenti $\mathrm{M}$, et al. Chemical constituents, radical scavenging activity and enzyme inhibitory capacity of fruits from Cotoneaster pannosus Franch. Food Funct 2017;8(5):1775-84.

15. Iram H, Rasool N, Riaz M, Ullah A, Bokhari T, Musharraf S, et al. GC-MS analysis, antioxidant and antimicrobial studies of Sophora mollis essential and fixed oil. Oxid Commun 2015;38:689-99.

16. Ferhat MA, Meklati BY, Smadja J, Chemat F. An improved microwave Clevenger apparatus for distillation of essential oils from orange peel. J Chromatogr A 2006;1112(1-2):121-6.

17. Dutta R, Sarkar U, Mukherjee A. Extraction of oil from Crotalaria juncea seeds in a modified Soxhlet apparatus: physical and chemical characterization of a prospective biofuel. Fuel 2014;116:794-2.

18. Riaz M, Rasool N, Bukhari I, Zubair M, Shahid M, Bokhari $\mathrm{T}$, et al. Antioxidant studies using sunflower oil as oxidative substrate and DNA protective assay by Antirrhinum majus. Oxid Commun 2013;36:542-52.

19. Afzal M, Shahid M, Jamil A. Phytochemical spectrum of essential oil of Paganum harmala by GC-MS and antimicrobial activity using sequential solvents fractions and essential oil. Asian J Chem 2014;26:574.

20. Powell WA, Catranis CM, Maynard CA. Design of selfprocessing antimicrobial peptides for plant protection. Lett Appl Microbiol 2000;31:163-8.

21. Salman M, Shahid M, Jamil A, Rehman S. Effect of Lactobacillos acidophillis bacterium on Bacillus cereus biofilm. J Pure Appl Microbiol 2014;8:3721-8.

22. Prasad S, Kashyap RS, Deopujari JY, Purohit HJ, Taori GM, Daginawala HF. Development of an in vitro model to study clot lysis activity of thrombolytic drugs. Thromb J 2006;4:14.

23. Kalpana KB, Srinivasan M, Menon VP. Antioxidant potential 
of aminothiazole derivative and its protective effect on $\mathrm{H}_{2} \mathrm{O}_{2}$ induced oxidative damage on pBR322 DNA and RBC cellular membrane. Mol Cell Biochem 2008;314(1-2):95-03.

24. Zárybnický T, Boušová I, Ambrož M, Skálová L. Hepatotoxicity of monoterpenes and sesquiterpenes. Arch Toxicol 2017;92(1):1-13.

25. Sharifi-Rad J, Sharifi-Rad M, Hoseini-Alfatemi SM, Iriti M, Sharifi-Rad M, Sharifi-Rad M. Composition, cytotoxic and antimicrobial activities of Satureja intermedia CA Mey essential oil. Int J Mol Sci 2015;16(8):17812-25.

26. Hajlaoui H, Mighri H, Aouni M, Gharsallah N, Kadri A. Chemical composition and in vitro evaluation of antioxidant, antimicrobial, cytotoxicity and anti-acetylcholinesterase properties of Tunisian Origanum majorana L. essential oil. Microb Pathog 2016;95:86-94.

27. Elagbar ZA, Naik RR, Shakya AK, Bardaweel SK. Fatty acids analysis, antioxidant and biological activity of fixed oil of Annona muricata L. seeds. J Chem 2016;2016:6948098.

28. Zengin H, Baysal AH. Antibacterial and antioxidant activity of essential oil terpenes against pathogenic and spoilage-forming bacteria and cell structure-activity relationships evaluated by SEM microscopy. Molecules 2014;19(11):17773-98.

29. Zouari S, Zouari N, Fakhfakh N, Bougatef A, Ayadi MA, Neffati M. Chemical composition and biological activities of a new essential oil chemotype of Tunisian Artemisia herbaalba Asso. J Med Plants Res 2010;4:871-80.

30. Zengin G, Uysal A, Gunes E, Aktumsek A. Survey of phytochemical composition and biological effects of three extracts from a wild plant (Cotoneaster nummularia Fisch. et Mey.): a potential source for functional food ingredients and drug formulations. PLoS One 2014;9(11):e113527.

31. Awolola GV, Koorbanally NA, Chenia H, Shode FO, Baijnath $\mathrm{H}$. Antibacterial and anti-biofilm activity of flavonoids and triterpenes isolated from the extracts of Ficus sansibarica Warb. subsp. sansibarica (Moraceae) extracts. Afr J Tradit Complement Altern Med 2014;11(3):124-31.

32. Grassmann J. Terpenoids as plant antioxidants. Vitam Horm 2015;72:505-35. 